\title{
Melonoside A: an w-Glycosylated Fatty Acid Amide from the Far-Eastern Marine Sponge Melonanchora kobjakovae
}

Alla G. Guzii ${ }^{\dagger}$ Tatyana N. Makarieva, ${ }^{*},{ }^{\dagger}$ Vladimir A. Denisenko, ${ }^{\dagger}$ Pavel S. Dmitrenok, ${ }^{\dagger}$ Aleksandra S. Kuzmich, ${ }^{\dagger}$ Sergey A. Dyshlovoy, ${ }^{\dagger,}{ }^{\ddagger}$ Gunhild von Amsberg, ${ }^{\ddagger}$ Vladimir B. Krasokhin $^{\dagger}$ and Valentin A. Stonik ${ }^{\dagger}$

${ }^{\dagger}$ G.B. Elyakov Pacific Institute of Bioorganic Chemistry, the Far-East Branch of the Russian Academy of Sciences, Vladivostok-22, Prospect 100-let Vladivostoku, 159, Russia

${ }^{*}$ Department of Oncology, Hematology and Bone Marrow Transplantation with Section Pneumology, Hubertus Wald-Tumorzentrum, University Medical Center Hamburg-Eppendorf, Hamburg, Germany

* Correspondence should be addressed. Tel: +7(4232)31-11-68. Fax: +7(4232)31-40-50. E-mail:

makarieva@piboc.dvo.ru

\section{Contents}

S2. List of previously reported first members of glycosylated fatty acid amide groups

S3, 4. Experimental Section

S5. Effect of the Melonoside A (1) on the apoptosis induction, cell cycle progression, as well as on autophagy induction in cisplatin-resistant germ cell tumor (GCT) NCCIT-R cell

S7. ${ }^{1} \mathrm{H}$ NMR spectrum $\left(700 \mathrm{MHz}, \mathrm{CD}_{3} \mathrm{OD}\right)$ of compound 1

$\mathrm{S} 8{ }^{13} \mathrm{C}$ NMR spectrum $\left(175 \mathrm{MHz}, \mathrm{CD}_{3} \mathrm{OD}\right)$ of compound 1

S9. COSY spectrum (700 MHz, $\mathrm{CD}_{3} \mathrm{OD}$ ) of compound 1

$\mathrm{S} 10$. HSQC spectrum (700 MHz, $\left.\mathrm{CD}_{3} \mathrm{OD}\right)$ of compound 1

$\mathrm{S} 11$. HMBC spectrum (700 MHz, $\mathrm{CD}_{3} \mathrm{OD}$ ) of compound 1

$\mathrm{S} 12$. NOESY spectrum $\left(700 \mathrm{MHz}, \mathrm{CD}_{3} \mathrm{OD}\right)$ of compound 1

S13. ROESY spectrum (700 MHz, $\left.\mathrm{CD}_{3} \mathrm{OD}\right)$ of compound 1

S14. ${ }^{1} \mathrm{H}$ NMR spectrum $\left(700 \mathrm{MHz}, \mathrm{CD}_{3} \mathrm{OD}\right)$ of compound 2

S15. GLC-MS of compound 5

S16. CD spectra for compounds 6, 7, 8, $(R)-(+)-2$-methoxypropyonic and (S)-(-)-2-methoxypropyonic acids

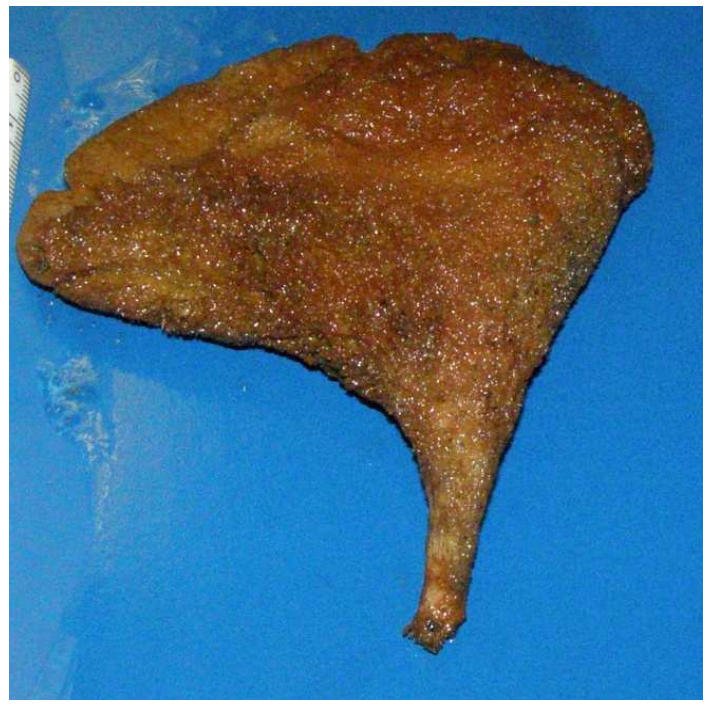

041-135 Melonanchora kobjakovae 
Previously reported first members of glycosylated fatty acid amide groups<smiles>[R]CC(=O)CCC(=O)O</smiles>

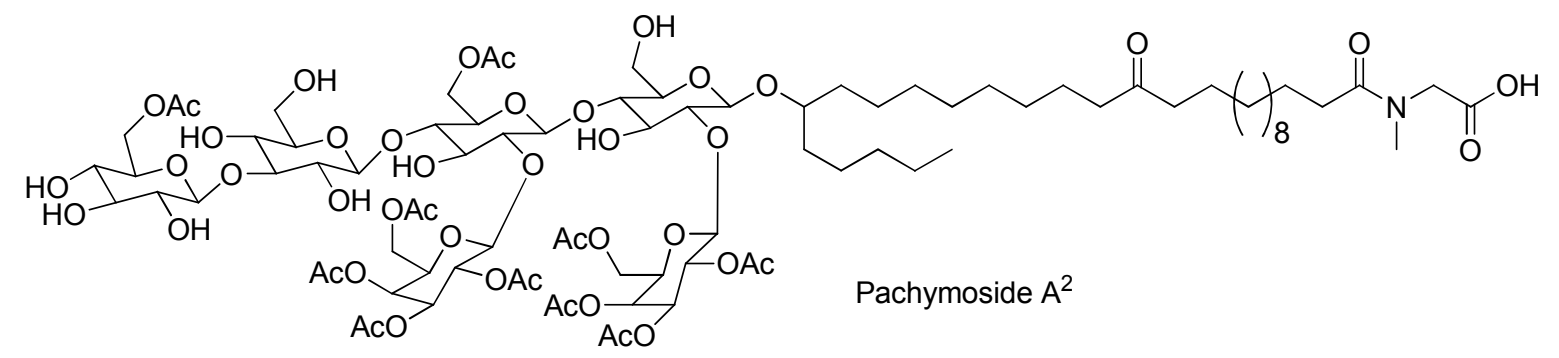

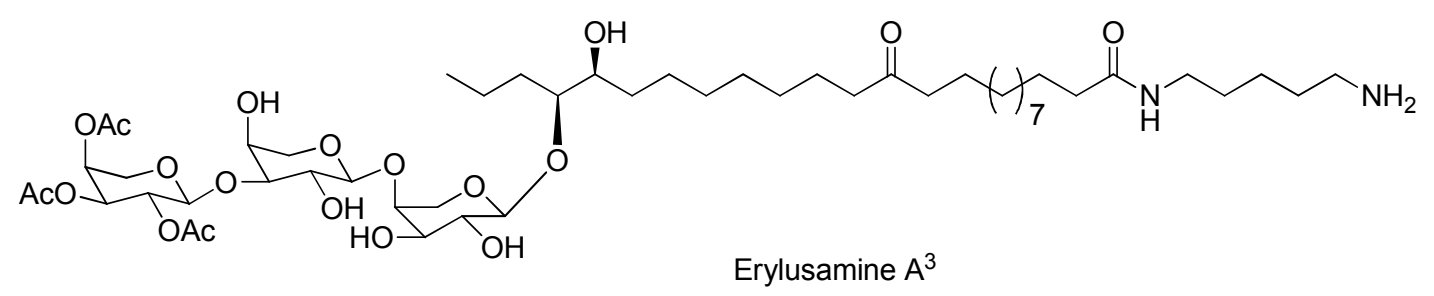

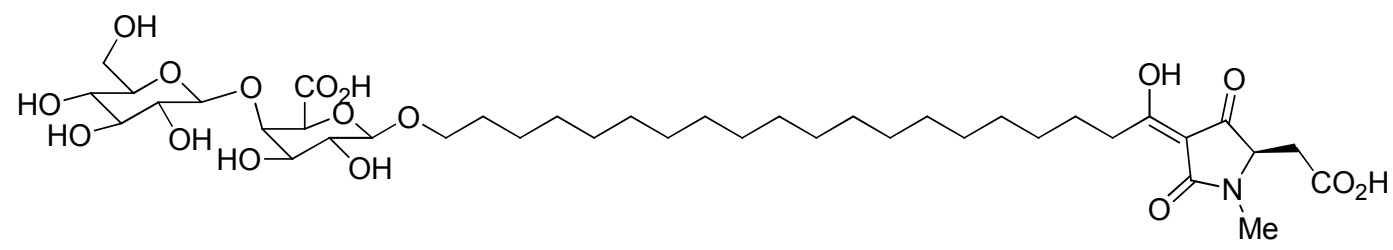

Ancorinoside $\mathrm{A}^{4}$<smiles>CC(CCCCCCCCCCCCCCOC1OC(O)C2C(O)C(O)C(O)C1C2O)C(=O)C1C(=O)N(C)C=C1O</smiles>

Epicoccamide $^{5}$

\section{REFERENCES}

(1) Tareq, F. S.; Kim, J. H.; Lee, M. A.; Lee, H. S.; Lee, Y. J.; Lee, J. S.; Shin, H. J. Org. Lett. 2012, 14, 14641467.

(2) Warabi, K.; Zimmerman, W. T.; Shen, J., Gauthier, A.; Robertson, M.; Finlay, B. B.; van Soest, R.; Andersen, R. J. Can. J. Chem. 2004, 82, 102-112.

(3) Sata, N.; Asai, N.; Matsunaga, S.; Fusetani, N. Tetrahedron 1994, 50, 1105-1110.

(4) Ohta, S.; Ohta, E.; Ikegami, S. J. Org. Chem. 1997, 62, 6452-6453.

(5) Wright, A. D.; Osterhage, C.; Konig, G. M. Org. Biomol. Chem. 2003, 1, 507-510. 


\section{Experimental Section}

General experimental procedure. Optical rotation was measured using a Perkin-Elmer 343 polarimeter. The ${ }^{1} \mathrm{H}$ and ${ }^{13} \mathrm{C}$ NMR spectra were recorded on a Bruker Avance III-700 spectrometer at 700 and $175 \mathrm{MHz}$, respectively. Chemical shifts were referenced to the corresponding residual solvent signal ( $\left.\delta \mathrm{H} 3.30 / \delta \mathrm{C} 49.6 \mathrm{for}_{\mathrm{CD}} \mathrm{OD}\right)$. ESI mass spectra (including HRESIMS) were obtained on an Agilent 6510 Q-TOF LC-MS spectrometer by direct infusion in $\mathrm{MeOH}$. CD spectra were recorded with an Applied Photophysics Chirascan plus spectropolarimeter. GC analisis was conducted on an Agilent 6580 Series apparatus, with the carrier gas $\mathrm{He}(1.7 \mathrm{~mL} / \mathrm{min}) \mathrm{using}$ a temperature gradient of $150{ }^{\circ} \mathrm{C}-230{ }^{\circ} \mathrm{C}(10 \mathrm{~min})$ at $3{ }^{\circ} \mathrm{C} / \mathrm{min}$ (for acetylated methyl glycosides) and a temperature gradient $100{ }^{\circ} \mathrm{C}-270{ }^{\circ} \mathrm{C}$ at $5{ }^{\circ} \mathrm{C} / \mathrm{min}$ (for 2-octyl glycosides) equipped with a capillary column HP-5 MS (30 m x $0.25 \mathrm{~mm}$ ). The temperatures of the injector and detector were 250 and $300^{\circ} \mathrm{C}$ respectively. GLC-MS analyses were done on a Hewlett Packard HP6890GC System using HP-5 MS capillary column at $270^{\circ} \mathrm{C}$, and an ionizing voltage was of $70 \mathrm{eV}$. Low-pressure column liquid chromatography was performed using YMC*Gel ODS-A (YMC Co., Ltd., Kioto, Japan) and sephadex LH-20 (Sigma, Chemical Co). HPLC was performed using an Shimadzu Instrument equipped with the differential refractometer RID-10A and a YMC-ODS-Am $(250 \times 10 \mathrm{~mm})$ column.

Animal Material. The sponge Melonanchora kobjakovae was collected by dredging during the 41 scientific cruise of the R/V “Academic Oparin", July 2011, near Urup Island (4602,1 N; 149 55,3 E, depth $121 \mathrm{~m}$ ). A voucher speciment is kept under the registration number PIBOC \#O41-135 in the marine invertebrates collection of the Pacific Institute of Bioorganic Chemistry (Vladivostok, Russia).

Extraction and Isolation. The EtOH extract of the sponge M. kobjakovae (dry weight $5.3 \mathrm{~g}$ ) was concentrated and partitioned between $n$-hexane and aqueous EtOH. The EtOH-soluble material was subjected to column chromatography on a reversed phase YMC*Gel ODS-A with a stepped gradient from $\mathrm{H}_{2} \mathrm{O}$ to EtOH. Fraction eluted whith $\mathrm{EtOH} / \mathrm{H}_{2} \mathrm{O}(80: 20)$ was purified by sephadex LH-20 (EtOH) with monitoring by HPLC. Preparative HPLC of the mixture (YMC-ODS-Am, 55:45:1\% EtOH- $\left.\mathrm{H}_{2} \mathrm{O}-\mathrm{NH}_{4} \mathrm{OH}\right)$ to give pure Melonoside A (1, $6.3 \mathrm{mg}, 0.11 \%$ based on dry weight of sponge).

Melonoside A (1): colorless glass; $[\alpha]_{\mathrm{D}}-20\left(c 0.18\right.$, EtOH) $;{ }^{1} \mathrm{H},{ }^{13} \mathrm{C}$ NMR data $\left(\mathrm{CD}_{3} \mathrm{OD}\right)$, Table 1 ; HRESIMS $m / z$ $788.4590[\mathrm{M}-\mathrm{H}]^{-}$(calculated for $\mathrm{C}_{43} \mathrm{H}_{66} \mathrm{NO}_{12}, 788.4591$ ); HRESIMS/MS of the ion $[\mathrm{M}-\mathrm{H}]^{-}$at $\mathrm{m} / z$ 788: 612 [M$\left.\mathrm{C}_{6} \mathrm{H}_{8} \mathrm{O}_{6}\right]^{-}$, (calc. for $\mathrm{C}_{37} \mathrm{H}_{58} \mathrm{NO}_{6} 418.3064$ ).

Ozonolysis of Melonoside A (1). Ozone was bubbled through a solution of $1(0.5 \mathrm{mg})$ in $\mathrm{MeOH}$ at a temperature of $-70{ }^{\circ} \mathrm{C}$ for $40 \mathrm{~min}$. The solution was analyzed by HRESIMS.

Compound 3: HRESIMS $m / z$ 353.1456 [M-H] $]^{-}$(calculated for $\mathrm{C}_{14} \mathrm{H}_{25} \mathrm{O}_{10}, 353.1453$ ).

Reductive amination of Melonoside A (1). A mixtute of $1(1.0 \mathrm{mg})$ and $\mathrm{NH}_{4} \mathrm{OAc}(3.0 \mathrm{mg})$ in $\mathrm{MeOH}(1 \mathrm{~mL})$ was treated with $\mathrm{NaBH} \mathrm{CN}_{3}(1.0$ $\mathrm{mg}$ ) and stirred at room temperature for 2 days. The reaction mixture was neutralized with dilute $\mathrm{CH}_{3} \mathrm{COOH}$. The volatiles were removed under reduced pressure and the residue was purified by YMC*Gel ODS-A column chromotography (55:45:1\% EtOH- $\left.\mathrm{H}_{2} \mathrm{O}-\mathrm{NH}_{4} \mathrm{OH}\right)$ to obtain 11,18-diaminomelonoside A (3, $\left.0.7 \mathrm{mg}\right):{ }^{1} \mathrm{H}$ NMR $\left(700 \mathrm{MHz}, \mathrm{CD}_{3} \mathrm{OD}\right) \delta$ $7.03(\mathrm{~d}, 8.5), 6.69(\mathrm{~d}, 8.5), 5.44(\mathrm{~m}), 5.38(\mathrm{~m}), 5.35(\mathrm{~m}), 4.26(\mathrm{~d}, 8.0), 3.91(\mathrm{~m}), 3.64(\mathrm{~m}), 3.58(\mathrm{~m}), 3.56(\mathrm{~m}), 3.41(\mathrm{t}$, 7.3), $3.40(\mathrm{~m}), 3.28(\mathrm{~s}), 3.20(\mathrm{~m}), 2.72(\mathrm{~m}), 2.19(\mathrm{~m}), 2.07(\mathrm{~m}), 1.70-1.54(\mathrm{~m}), 1.40-1.33(\mathrm{~m})$; HRESIMS $\mathrm{m} / z$ $792.5393[\mathrm{M}+\mathrm{H}]^{+}$(calculated for $\left.\mathrm{C}_{43} \mathrm{H}_{74} \mathrm{~N}_{3} \mathrm{O}_{10}, 792.5369\right), \mathrm{m} / z 396.7[\mathrm{M}+2 \mathrm{H}]^{2+}$

Acetylation of 11,18-diaminomelonoside A (2). The 11,18-diaminomelonoside A (2) was treated with $20 \%$ $\mathrm{Ac}_{2} \mathrm{O}$ in $\mathrm{MeOH}$ during $12 \mathrm{~h}$ at $25{ }^{\circ} \mathrm{C}$ in the presence of catalytic amounts of DMAP. Removal of the volatile material under reduced pressure gave a residue of $N, N^{\prime}$-diacetamide of melonoside A $(4,0.5 \mathrm{mg})$ : HRESIMS $\mathrm{m} / z$ 912.5548 [M+Na] ${ }^{+}$(calculated for $\mathrm{C}_{48} \mathrm{H}_{79} \mathrm{~N}_{3} \mathrm{NaO}_{12}, 912.5556$ )

Ozololysis-Reduction of $N, N^{\prime}$-diacetamide of melonoside A (4). Ozone was bubbled through a solution of $4(0.5 \mathrm{mg})$ in $\mathrm{MeOH}$ at $-70{ }^{\circ} \mathrm{C} 1 \mathrm{~h}$. The solution was cooled and treated with an excess of $\mathrm{NaBH}_{4}(3 \mathrm{mg})$. The mixture was left at room temperature overnight and quenched with acetic acid (to $\mathrm{pH}=7$ ). The mixture was evaporated and treated with $\mathrm{Ac}_{2} \mathrm{O} /$ pyridine $(1: 1,0.5 \mathrm{~mL})$ at room temperature, overnight. The resulting mixture of peracetates was analyzed by HRESIMS and GLC-MS.

Compound 5: HRESIMS $m / z 457.3278[\mathrm{M}+\mathrm{H}]^{+}$(calculated for $\mathrm{C}_{24} \mathrm{H}_{45} \mathrm{~N}_{2} \mathrm{O}_{6}, 457.3272$ ). 
Preparation of aglycone melonoside A (6). $5 \% \mathrm{HCl}$ in $\mathrm{MeOH}(1 \mathrm{~mL})$ was added to $\mathbf{1}(0.5 \mathrm{mg})$ and solution was heating for $4 \mathrm{~h}$ at $100{ }^{\circ} \mathrm{C}$. The volatiles were removed under reduced pressure and the residue was purified by

S3

YMC*Gel ODS-A column chromotography $(70 \% \mathrm{EtOH})$ to obtain aglycone melanoside A (6): $[\alpha]_{\mathrm{D}}-30(c$ 0.02, EtOH); ${ }^{1} \mathrm{H}$ NMR $\left(700 \mathrm{MHz}, \mathrm{CD}_{3} \mathrm{OD}\right) \delta 7.03(\mathrm{~d}, 8.5), 6.69(\mathrm{~d}, 8.5), 5.35(\mathrm{~m}), 5.30(\mathrm{~m}), 3.54(\mathrm{~m}), 3.53(\mathrm{t}, 6.6), 3.41(\mathrm{t}, 7.3)$, $3.27(\mathrm{~s}), 2.72(\mathrm{~m}), 2.47(\mathrm{t}, 7.2), 2.42(\mathrm{~m}), 2.27(\mathrm{~m}), 2.11(\mathrm{~m}), 2.04(\mathrm{~m}), 1.70-1.59(\mathrm{~m}), 1.57-1.50(\mathrm{~m}), 1.38-1.30(\mathrm{~m})$, 1.28-1.25 (m); ${ }^{13} \mathrm{C}$ NMR $\left(175 \mathrm{MHz}, \mathrm{CD}_{3} \mathrm{OD}\right) \delta 214.7,214.1,175.8,157.6,132.5,132.0,131.6,131.4,130.5,129.8$, $116.9,83.5,63.6,59.1,44.1,44.0,43.96,43.94,42.2,36.3,34.7,34.2,31.4,30.9,30.8,30.6,28.7,27.5,25.3,25.2$, 25.1, 24.3 23.3; HRESIMS $m / z 612.4264$ [M-H] ${ }^{-}$(calculated for $\mathrm{C}_{37} \mathrm{H}_{58} \mathrm{NO}_{6}, 612.4270$ ).

Monosaccharide analyses. $5 \% \mathrm{HCl}$ in $\mathrm{MeOH}(1 \mathrm{~mL})$ was added to $\mathbf{1}(0.5 \mathrm{mg})$ and solution was heating during $4 \mathrm{~h}$ at $100{ }^{\circ} \mathrm{C}$. Then the solvent was removed by a steam of Argon and a mixture of pyridine and $\mathrm{Ac}_{2} \mathrm{O}(1: 1,0.4 \mathrm{~mL})$ was added. After stirring overnight at room temperature the mixture was concentrated in vacuo. GC analysis of the residue by comparision with the authentic samples prepared by the same procedure showed glucuronic acid.

Acid hydrolysis and determination of the absolute configuration of monosaccharide. A solution of $\mathbf{1}(0.5 \mathrm{mg})$ in $1 \mathrm{M}$ TFA (0.5 $\mathrm{mL})$ in a sealed vial was heated at $100^{\circ} \mathrm{C}$ for $2 \mathrm{~h}$. The water layer was then washed with $\mathrm{CHCl}_{3}(3 \times 0.5 \mathrm{~mL})$ and evaporated to dryness. One drop of concentrated TFA and $0.3 \mathrm{~mL}$ of $R$-(-)-2-octanol (Aldrich) were added to the residue, and the reaction mixture was heated on a glycerol bath at $130^{\circ} \mathrm{C}$ for $6 \mathrm{~h}$. The solution was evaporated and treated with a mixture of pyridine/acetyc anhydride $(1: 1,0.4 \mathrm{~mL})$ for $20 \mathrm{~h}$ at room temperature. The acetylated 2-octylglycoside was analyzed by $\mathrm{GC}$ using the corresponding authentic sample prepared by the same procedure. The following peaks were detected in the hydrolysate: $33.93,34.46,34.70,34.82 \mathrm{~min}$. The retention times for authentic samples were $33.91,34.44,34.70$, $34.80 \mathrm{~min}$ ( $D$-glucuronic acid) and 33.42, 33.87, 34.46, $35.09 \mathrm{~min}$ ( $L$-glucuronic acid).

Synthesis of the $(S)$ - and $(\boldsymbol{R})$ - $N$-2-methoxypropyl tyramines. A mixture of $(R)-(+)-2$-methoxypropyonic acid (Aldrich) (2.0 mg), DMAP $(1.0 \mathrm{mg})$, tyramine $(2.7 \mathrm{mg})$, EDC (1-ethyl-3-[3-dimethylaminopropyl]carbodiimide hydrochloride $(2.0 \mathrm{mg}) \mathrm{in} \mathrm{EtOH}(1 \mathrm{~mL})$ was heated $1 \mathrm{~h}$ and stirred at room temperature for $12 \mathrm{~h}$. The product was purified by HPLC (YMC-ODS-Am, 30\% EtOH/0.1\% TFA): ${ }^{1} \mathrm{H}$ NMR $\delta 7.02$ (d, 8.4), 6.69 (d, 8.4), 3.64 (q, 6.7) 3.40 (m), 3.27 (s), 2.71 (t, 7.3), 1.25 (d, 6.7); HRESIMS m/z 224.1280 [M+H] (calculated for $\mathrm{C}_{12} \mathrm{H}_{18} \mathrm{NO}_{3}$, 224.1281), $246.1096[\mathrm{M}+\mathrm{Na}]^{+}$(calculated for $\mathrm{C}_{12} \mathrm{H}_{17} \mathrm{NNaO}_{3}, 246.1101$ ).

In an entirely analogous way, the (S)-isomer was obtained using (S)-(-)-2-methoxypropyonic acid (Aldrich).

Cell lines and culture conditions. The cisplatin-resistant subline NCCIT-R has been generated as reported before from the NCCIT cell line, which was purchased from DSMZ (Braunschweig, Germany). ${ }^{1,2}$ Both cell lines were cultured according to the manufacturers instructions in 10\% FBS/DMEM F-12 media. Cells were continuously kept in culture for a maximum of 3 months, and were routinely inspected microscopically for stable phenotype and regularly checked for contamination with mycoplasma. Cell line authentication was performed by DSMZ (Braunschweig, Germany) using highly polymorphic short tandem repeat loci. ${ }^{3}$

Cell cycle and apoptosis induction analysis. The cell cycle distribution was analyzed by flow cytometry using PI staining as described before with slight modifications. ${ }^{4}$ In brief, cells were pre-incubated overnight in 6 -well plates $\left(2 \times 10^{5}\right.$ cells/well in $2 \mathrm{~mL}$ of medium per well). The medium was changed to fresh medium containing different concentrations of the melonoside A (1). After $48 \mathrm{~h}$ of treatment, cells were harvested with a trypsin-EDTA solution, fixed, stained, and analysed by FACS. The results were quantitatively analyzed using Cell Quest Pro software. Cells appeared in sub-G1 fraction were assumed as apoptotic.

Western blotting Western blotting was performed as described before. ${ }^{5}$ For detection of the proteins following primary and secondary antibody were used: anti-LC3B-I/II (Cell Signaling, \#2775, 1:1000), anti-SQSTM1/p62 (Cell Signaling, \#5114, 1:1000), anti- $\alpha$-tubulin (Sigma-Aldrich, T5168, 1:10000), anti-mouse IgG-HRP (GE Healthcare, NXA931, 1:10000), anti-rabbit IgG-HRP (Cell Signaling, \#7074, 1:5000). Signals were detected using the ECL chemiluminescence system (Thermo Scientific, Rockford, IL, USA) according to the manufacturer's protocol. 
Effect of the melonoside A (1) on the apoptosis induction, cell cycle progression, as well as on autophagy induction in cisplatin-resistant germ cell tumor (GCT) NCCIT-R cells. FACS analysis revealed slight apoptosis induction in NCCIT-R cells after $48 \mathrm{~h}$ of treatment with $10 \mu \mathrm{M}$ of the melonoside A (1) (Fig. 1A), while no alteration of cell cycle in the treated cells was observed (data not shown). We investigated the effect of the melonoside A (1) on the expression of autophagy-related proteins LC3B (isoforms LC3B-I and LC3B-II) and SQSTM1/p62. We have observed the downregulation of both LC3B-II isoform and SQSTM1/p62 following the substance treatment (Fig. 1B). LC3B-II is a phosphatidylethanolamine conjugated isoform of LC3B protein, which is recruited to autophagosomal membranes. SQSTM1/p62 is a cargo protein that targets and binds other proteins to deliver them to autophagosomes for selective autophagy. During autophagy autophagosomes fuse with lysosomes and intra-autophagosomal components are degraded by lysosomal hydrolases. ${ }^{6}$ Therefore decreased levels of LC3BII and SQSTM1/p62 were previously associated with increased autophagy flux. ${ }^{6,7}$ The observed effects of the melonoside A (1) in NCCIT-R cells were different from the effect of chloroquine (CQ) - a well-known autophagy inhibitor - which induced upregulation of LC3B-II and SQSTM1/p62 (Fig. 1B). Thus our results strongly suggest melonoside A (1) to induce autophagy in NCCIT-R cells, while apotosis was only slightly induced. NCCIT-R cells are known to be resistant to the cytotoxic effect of apoptosis inducing agent cisplatin. ${ }^{1,8}$ We have previously shown that induction of cytotoxic autophagy by another marine-derived alkaloid monanchocidine $\mathrm{A}$ in the same cell line leads to the cancer cell death and is related (due to the non-apoptotic mechanism of action) to the ability of the compound to overcome the cisplatin resistance. ${ }^{1}$ Therefore, drugs which are able to induce cytotoxic autophagy may also be promising as prototypes of chemotherapeutic agents for the treatment of drug-resistant tumors.

A

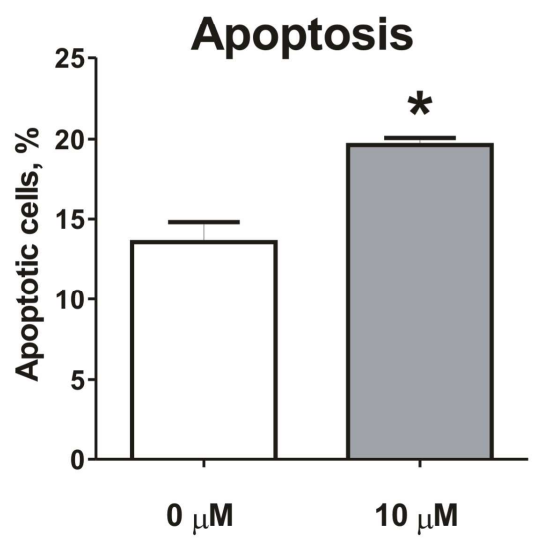

B

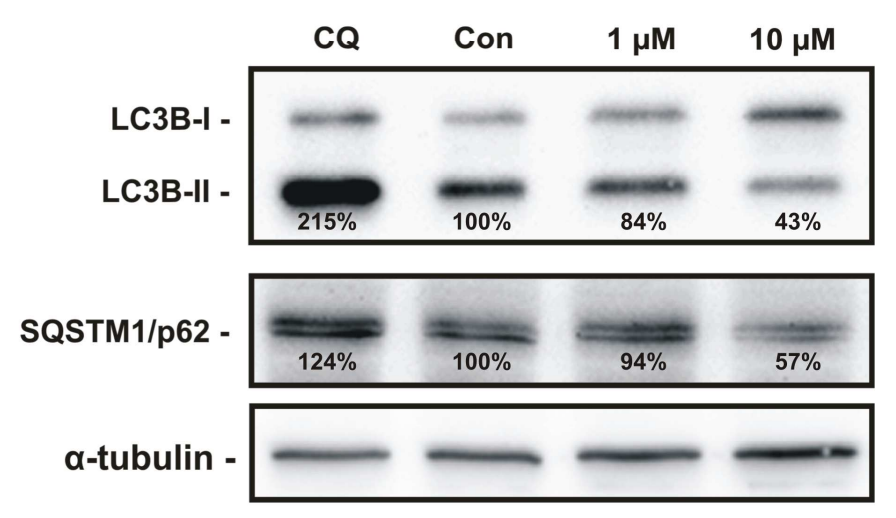

Figure 1. Effect of compounds on NCCIT-R cells. A, Flow cytometry analysis of NCCIT-R cells treated with the melonoside A (1) for $48 \mathrm{~h}$. Cell cycle phase distribution was analyzed and quantified using the Cell Quest Pro software and the cells appeared as sub-G1 population were assumed to be apoptotic. Significant difference from the control is shown as follows: ${ }^{*} \mathrm{p}<0.05$ (Student's t-test). B, Western blotting analysis of protein extracts of NCCIT-R cells treated with melonoside A (1) for $48 \mathrm{~h}$. Cells treated with $50 \mu \mathrm{M}$ of chloroquine (CQ) for $48 \mathrm{~h}$ were used as positive control. $\alpha$-Tubulin was used as a reference protein. The LC3B-II and SQSTM1/p62 signals was quantified and normalized against the correspondent signal of $\alpha$-Tubulin. The signal intensities ( $\%$ of control) are indicated on the figure.

\section{REFERENCES}

(1) Port, M.; Glaesener, S.; Ruf, C.; Riecke, A.; Bokemeyer, C.; Meineke, V.; Honecker, F.; Abend, M. Mol Cancer 2011, 10, 52.

(2) Oechsle, K.; Honecker, F.; Cheng, T.; Mayer, F.; Czaykowski, P.; Winquist, E.; Wood, L.; Fenner, M.; Glaesener, S.; Hartmann, J. T.; Chi, K.; Bokemeyer, C.; Kollmannsberger, C. Ann Oncol. 2011, 22, $2654-2660$.

(3) Dyshlovoy, S. A.; Hauschild, J.; Amann, K.; Tabakmakher, K. M.; Venz, S.; Walther, R.; Guzii, A. G.; Makarieva, T. N.; Shubina, L. K.; Fedorov, S.N.; Stonik, V. A.; Bokemeyer, C.; Balabanov, S.; Honecker, F.; Amsberg, G. V. Oncotarget 2015, 6, 17328-17341.

(4) Dyshlovoy, S. A.; Menchinskaya, E. S.; Venz, S.; Rast, S.; Amann, K.; Hauschild, J.; Otte, K.; Kalinin, V. I.; Silchenko, A. S.; Avilov, S. A.; Alsdorf, W.; Madanchi, R.; Bokemeyer, C.; Schumacher, U.; Walther, R.; Aminin, D. L.; Fedorov, S. N.; Shubina, L. K.; Stonik, V. A.; Balabanov, S.; Honecker, F.; von Amsberg, G. Int J Cancer 2016, 138, 2450-2465. 
(5) Dyshlovoy, S. A.; Venz, S.; Shubina, L. K.; Fedorov, S. N.; Walther, R.; Jacobsen, C.; Stonik, V. A.; Bokemeyer, C.; Balabanov, S.; Honecker, F. J Proteomics 2014, 96, 223-239.

(6) Klionsky, D. J.; Abdalla, F. C.; Abeliovich, H.; Abraham, R. T.; Acevedo-Arozena, A.; Adeli, K.; Agholme, L.; Agnello, M.; Agostinis, P.; Aguirre-Ghiso, J. A.; Ahn, H. J.; Ait-Mohamed, O.; et al. 2012, 8, 445544.

(7) Kallifatidis, G.; Hoepfner, D.; Jaeg, T.; Guzman, E. A.; Wright, A. E. Mar Drugs 2013, 11, 3500-3516.

(8) Glaesener, S.; Honecker, F.; Veltman, I. M.; Gillis, A. J. M.; Rohlfing, T.; Streichert, T.; Otto, B.; Brummendorf, T. H.; Looijenga, L. H. J.; Bokemeyer, C.; Balabanov, S. J. Proteom. Res., 2008, 7, 3890-3899. 
S7

${ }^{1} \mathrm{H}$ NMR spectrum (700 MHz, $\mathrm{CD}_{3} \mathrm{OD}$ ) of compound 1

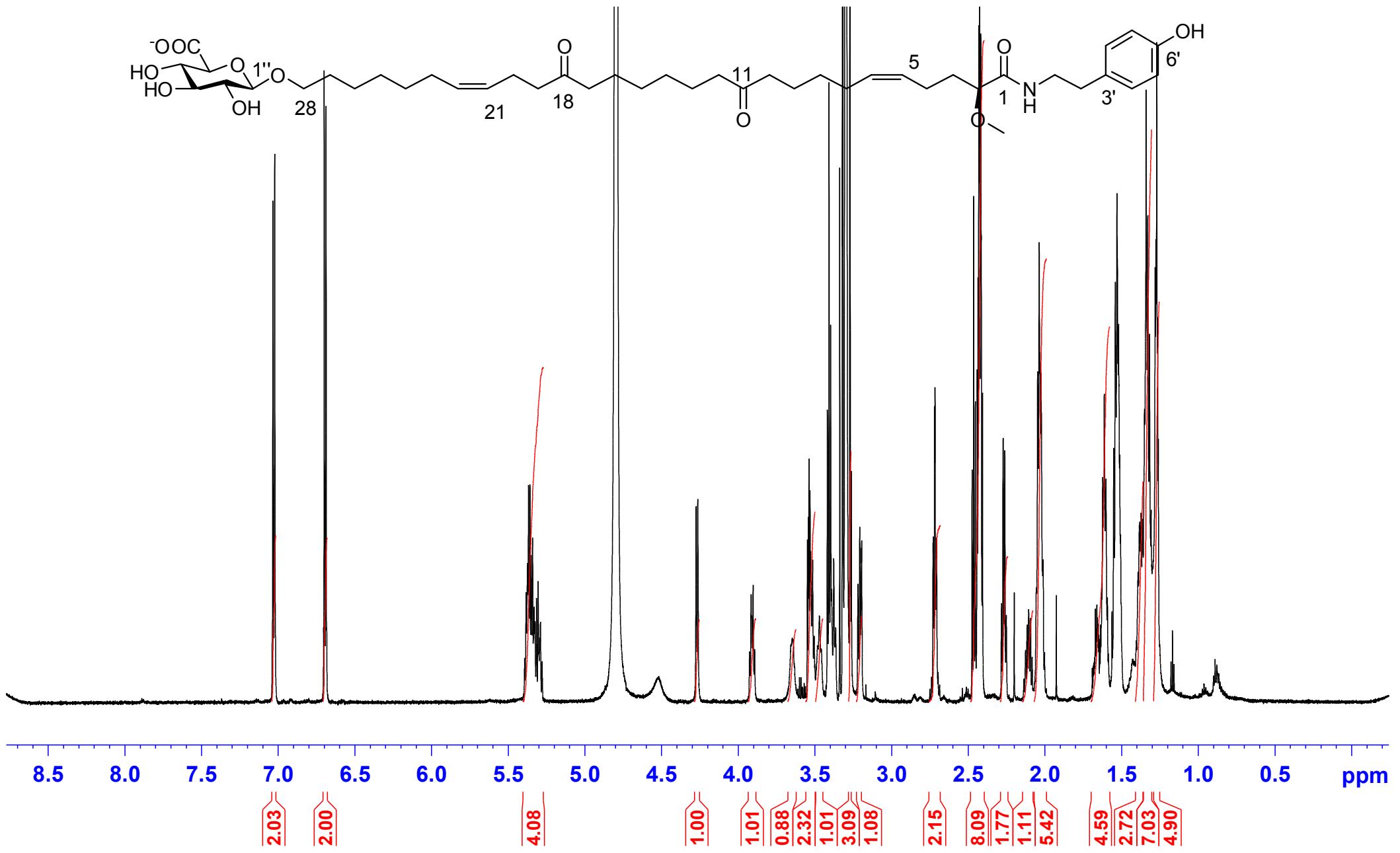


${ }^{13} \mathrm{C}$ NMR spectrum $\left(175 \mathrm{MHz}, \mathrm{CD}_{3} \mathrm{OD}\right)$ of compound $\mathbf{1}$

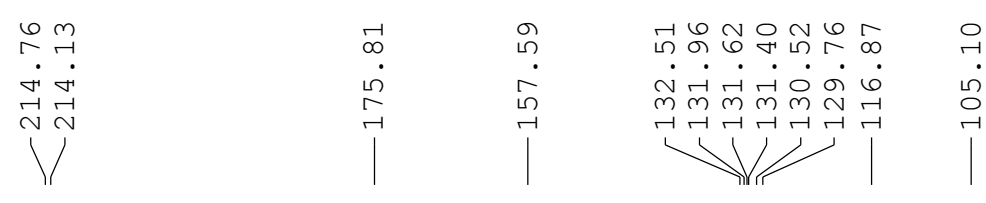

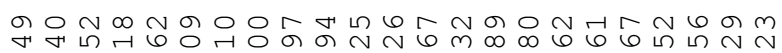
ભ

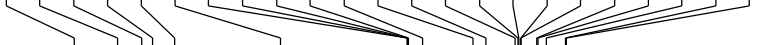

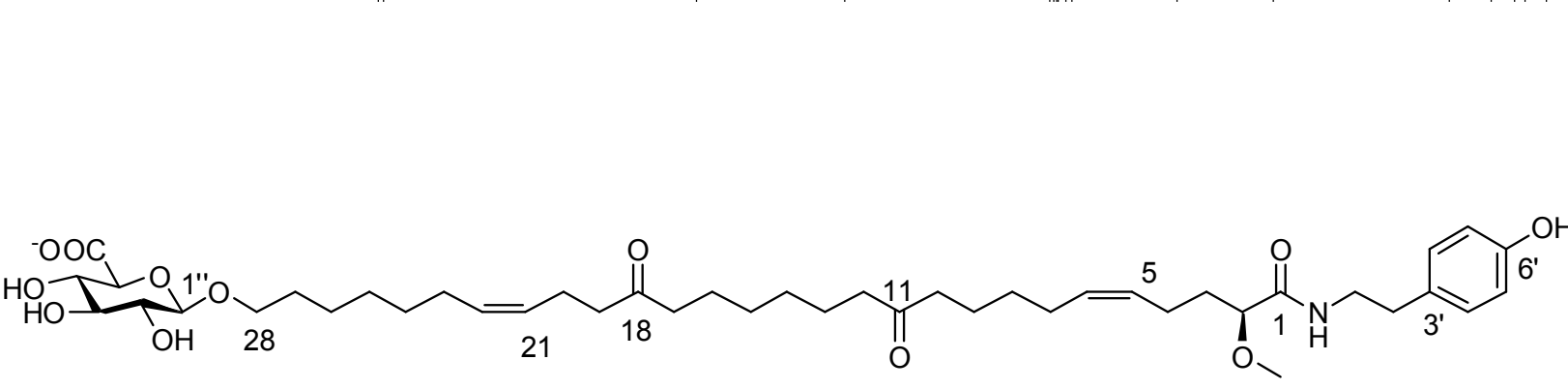

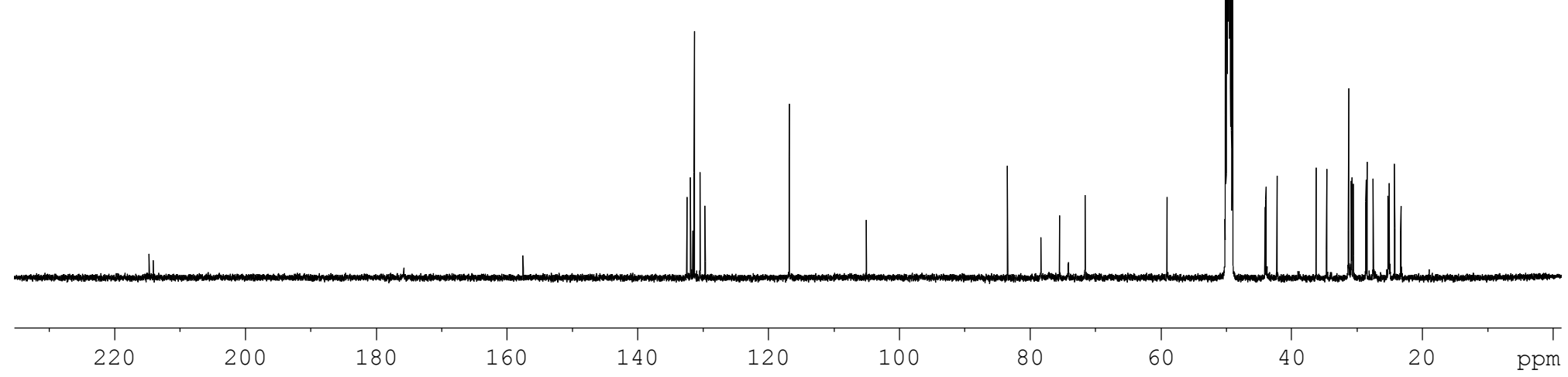


COSY spectrum (700 MHz, $\left.\mathrm{CD}_{3} \mathrm{OD}\right)$ of compound 1

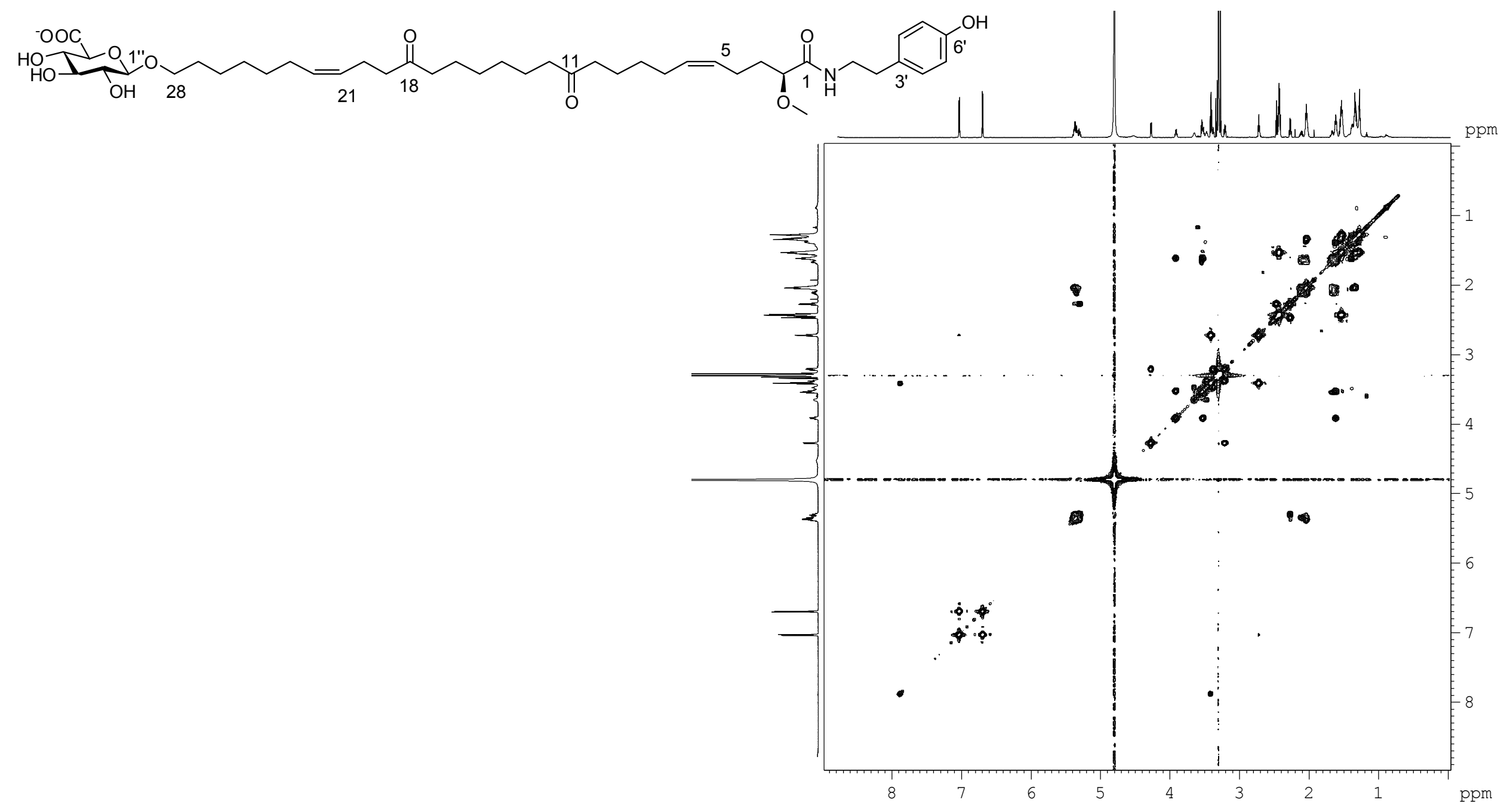


HSQC spectrum (700 MHz, $\left.\mathrm{CD}_{3} \mathrm{OD}\right)$ of compound $\mathbf{1}$

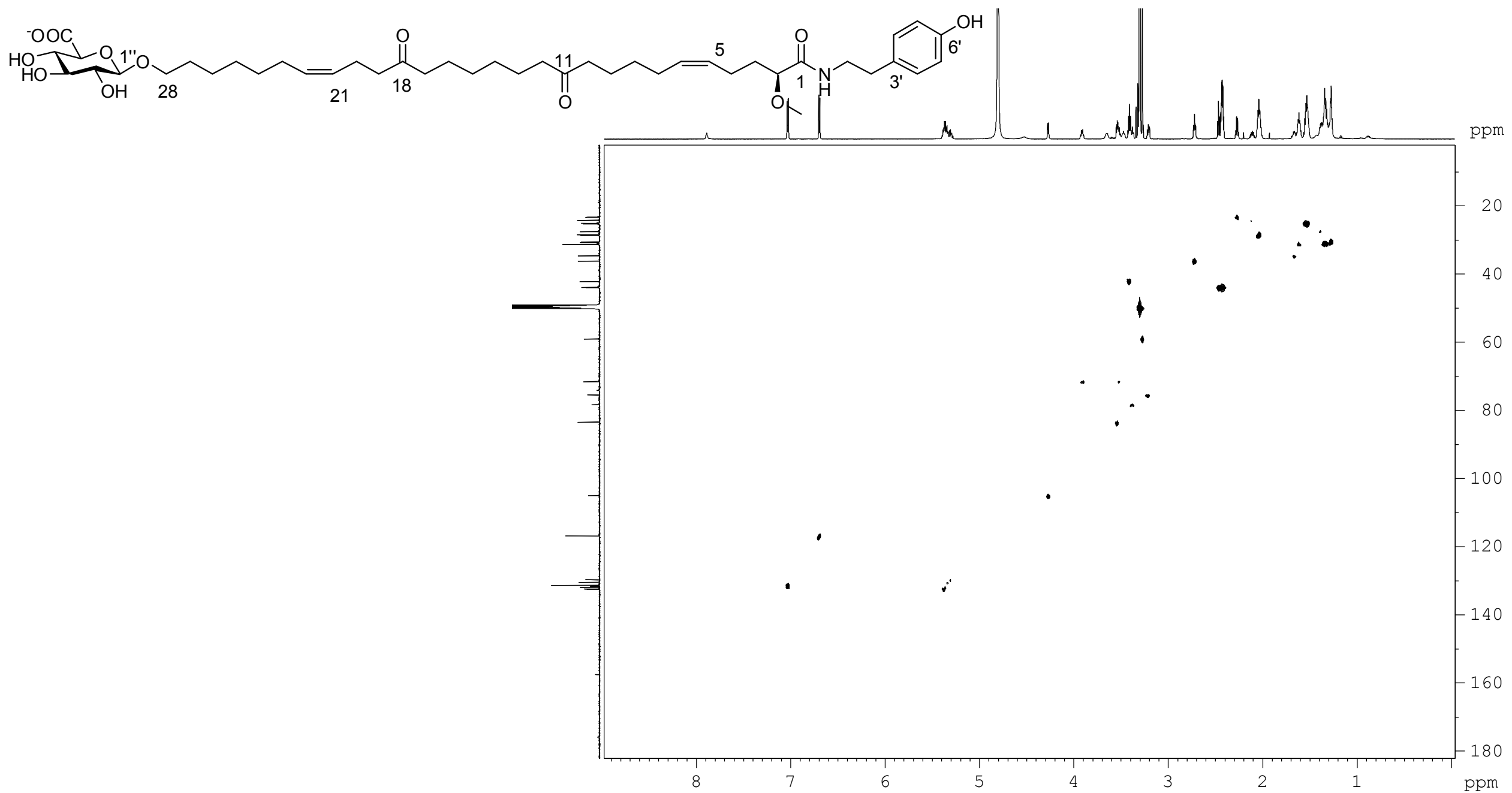




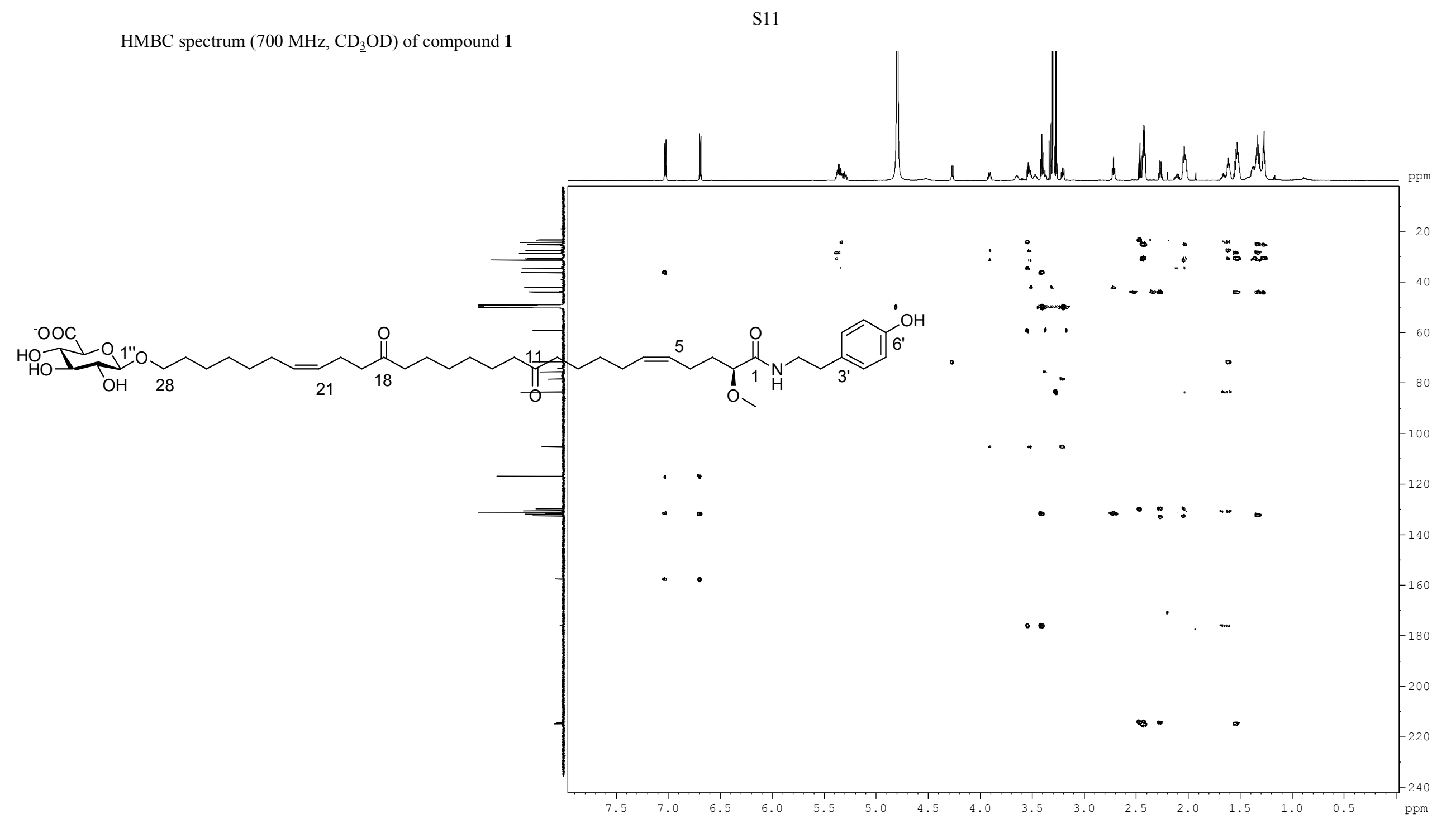


NOESY spectrum (700 MHz, $\mathrm{CD}_{3} \mathrm{OD}$ ) of compound $\mathbf{1}$

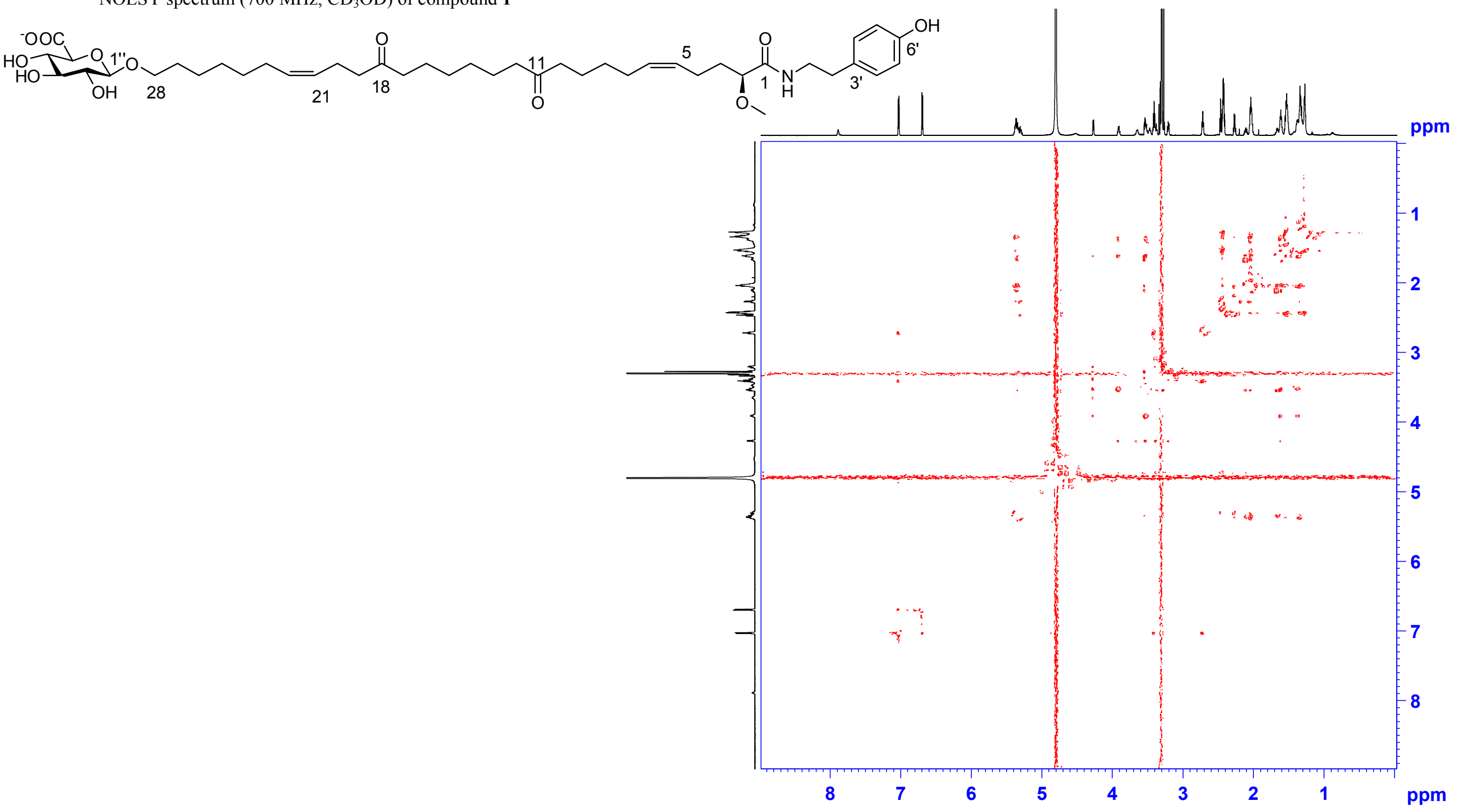


ROESY spectrum (700 MHz, $\left.\mathrm{CD}_{3} \mathrm{OD}\right)$ of compound $\mathbf{1}$

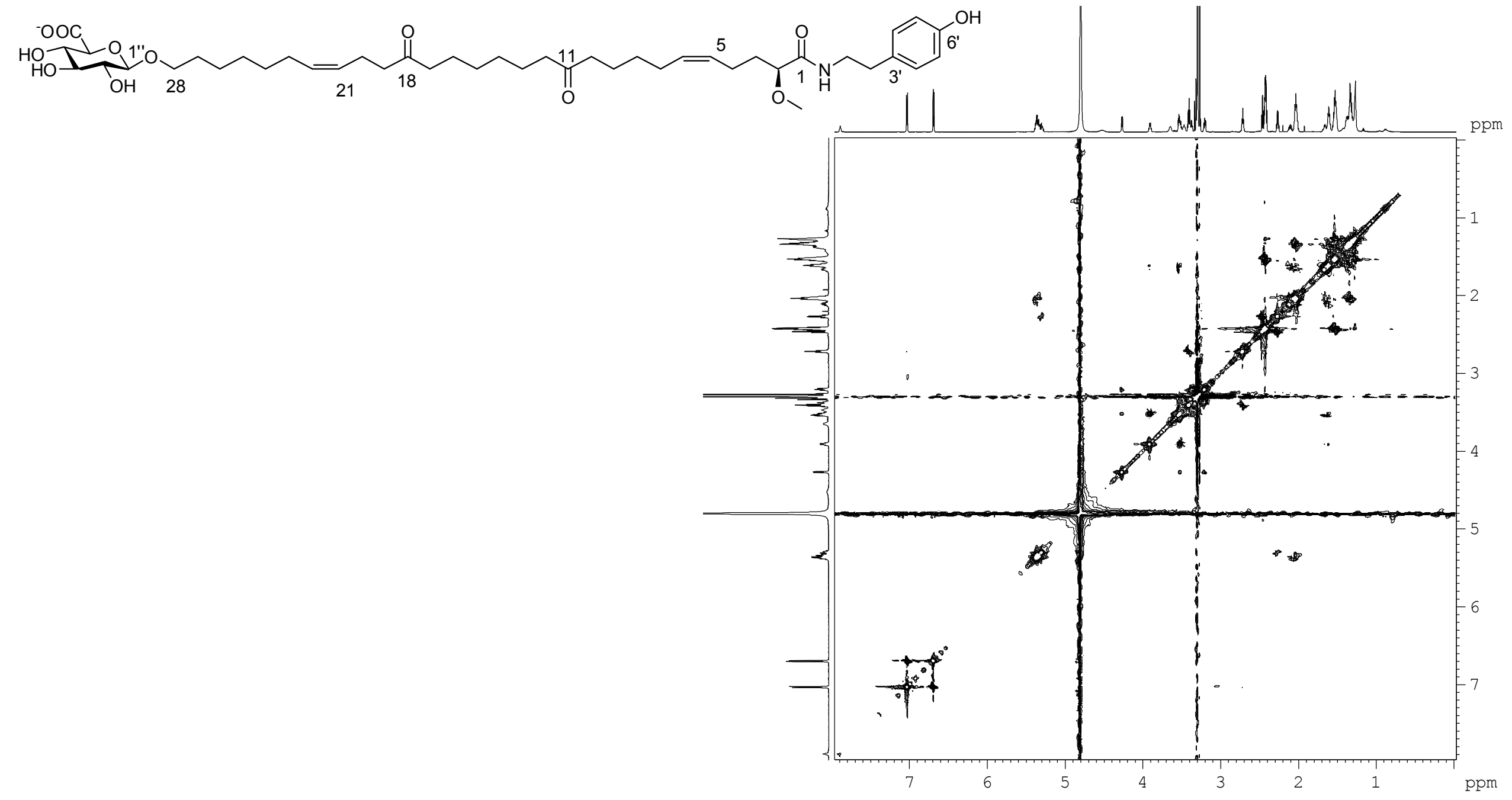




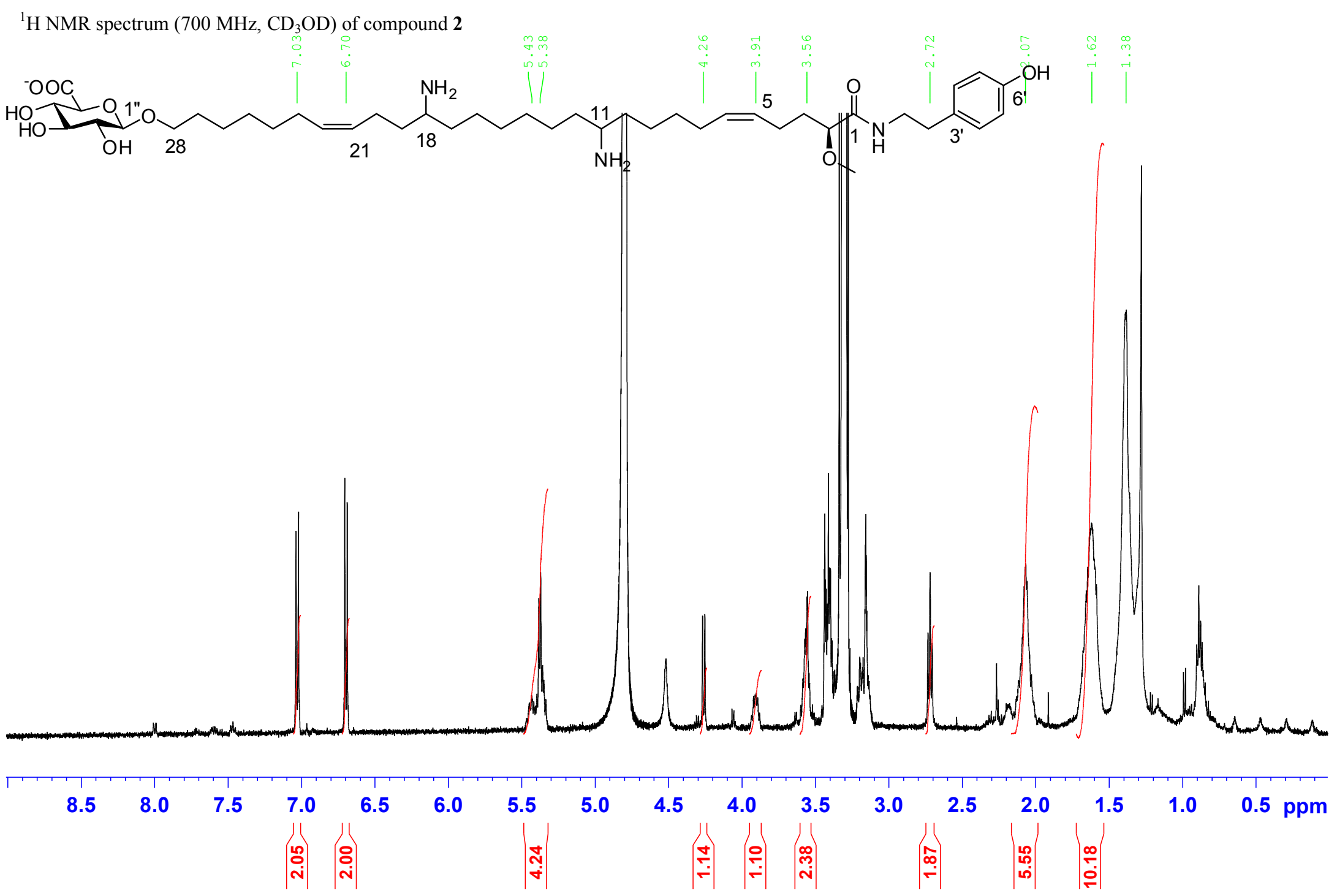


GLC-MS of compound 5 (HP-5 MS capillary column at $270^{\circ} \mathrm{C}$, and an ionizing voltage was of $70 \mathrm{eV}$ )

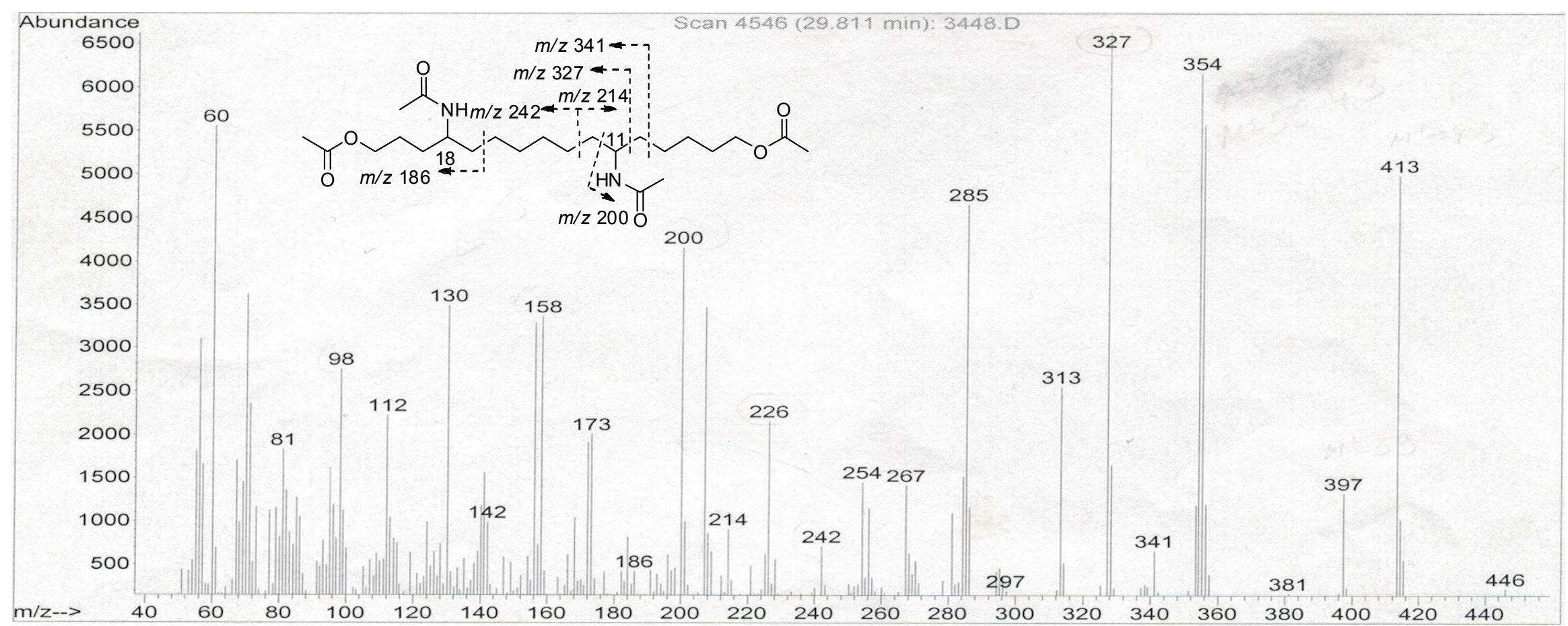


CD spectra for compounds 6, $(S)-(-)-2$-methoxypropyonic acids $(7 \mathbf{a}), 7 \mathbf{b},(R)-(+)-2$-methoxypropyonic $(\mathbf{8 a})$ and $\mathbf{8 b}$

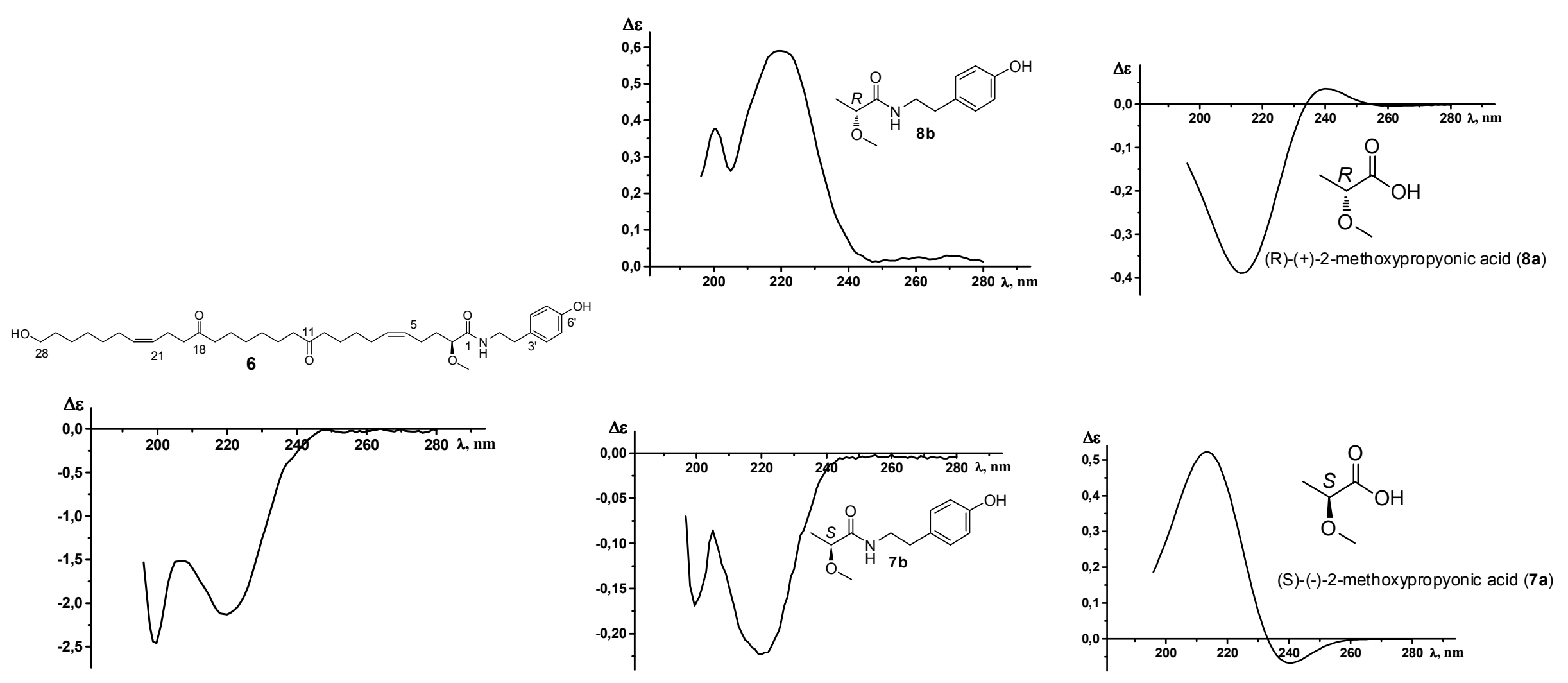

